\title{
THE OFFSPRING OF A CAPTURED FEMALE BASILARCHIA PROSERPINA.
}

By William L. W. Field,

\author{
Milton, Mass.
}

A female Basilarchia proserpina, taken at Springfield, Vt., August 14, 1908, refused to oviposit on the leaves of any available species of birch, poplar, or willow, but when furnished with wild cherry $^{1}$ leaves deposited thirty-one eggs, from sixteen of which offspring were reared to maturity. Of these offspring, nine (five males and four females) closely resembled the mother, and seven (four males and three females) were of the white-banded arthemis type, called by Edwards (1879) form lamina.

The accompanying plate shows the mother - much the worse for wear after her long captivity - and four of her offspring, a pair of each type. The entire series is now in the Museum of Comparative Zoölogy at Harvard University.

These observations, considered in the light of the Mendelian principles of heredity, give fresh support to the view of Scudder (1889) and others, who have believed proserpina to be a hybrid between arthemis and astyanax. The observed facts accord with those noted by Edwards, who in 1877 reared three arthemis and one proserpina from eggs deposited by a proserpina captured in the Catskill region; and in addition they bring out some new points:

First, the evidence of proserpina's hybridity furnished by her choice of an astyanax food-plant. In the opinion of collectors generally, the occurrence of a Basilarchia larva upon wild cherry plausibly identifies it as astyanax; and I find no record of the use of this food-plant by arthemis.

Second, some basis for a guess as to the specific identity of her mate. Springfield, Vt., is north of the zone in which proserpina ordinarily occurs, and it seems probable that the male parent of this diverse brood was of the arthemis (lamina) type.

Third, the approximately even division of the offspring between the two types, in a region where proserpina has heretofore been

1 Prunus serotina. 
unknown, while arthemis (lamina) is abundant, and always, so far as observation has shown, breeds true.

Edwards $(1877,1879)$ drew from his observations the conclusion that arthemis (lamina) and proserpina were to be referred to a single dimorphic species, flying in company with astyanax along the narrow zone where their ranges overlapped,- indeed dimorphic only in that zone,- yet never interbreeding with the other species. Mendel's work lay buried and forgotten; and no one realized that this dimorphism might under certain circumstances be a criterion of hybridity. The occurrence of other apparently hybrid Basilarchias (astyanax-archippus and arthemis-archippus) has been recorded (see Scudder, 1889, and Field, 1904), but its full meaning seems to have been overlooked. The cumulative significance of the various published observations of the genus Basilarchia in the eastern United States is contrary to Edwards's interpretation.

Our working hypothesis may now be that proserpina is a hybrid between arthemis and astyanax, in which the dark coloring of astyanax incompletely dominates the white band of arthemis. ${ }^{1}$ In the narrow belt in which the hybrids commonly occur, these heterozygous individuals must often breed together, producing offspring of which 50 per cent. must resemble the parents (i.e., are heterozygotes), while 25 per cent. are pure dominants (astyanax) and 25 per cent. are pure recessives (arthemis). ${ }^{2}$ Farther north, where astyanax seems not to thrive, but the recessive white-banded arthemis holds sway, occasional stray examples of proserpina, mating with arthemis, will yield offspring of which 50 per cent. will be proserpina and 50 per cent. pure arthemis. In this division the Springfield brood probably belongs. South of the zone of hybridization, the white band must be almost swamped; for when proserpina mates with astyanax, the offspring will all be dark, and half of them will be pure dominants (astyanax). The occasional white-banded Basilarchias ${ }^{3}$ taken on Long Island or in New Jersey, or in other places south of the usual range of arthemis, may be

\footnotetext{
${ }^{1}$ Such incomplete dominance is a widely-recognized phenomenon in Mendelian inheritance. See Bateson (1909) and Davenport (1910).

2 The name lamina now appears to be superfluous, as we are assuming that there is but one form of arthemis.

3 Ursula [=astyanax] var. albofasciata Newcomb (1907).
} 
regarded as extracted recessives (arthemis), due to the interbreeding of southward-spreading heterozygotes (proserpina).

Moreover, wherever either arthemis or astyanax mingles with the widely-distributed archippus, we should look carefully for further evidences of hybridization involving that species.

Viewed thus, the Basilarchias of eastern North America constitute a group of unusual interest to students of organic evolution, and supply attractive material for experimental investigation.

\section{BIBLIOGRAPHY.}

Bateson, W.

1909. Mendel's Principles of Heredity. Cambridge, Eng.

DAvENPoRT, C. B.

1910. The imperfection of dominance and some of its consequences. Am. Nat., xliv, 129-135.

Edwards, W. H.

1877. Notes on Limenitis proserpina and arthemis. Can. Ent., ix., 114.

1879. Butterflies of North America, II, Limenitis I. Boston and New York.

Field, W. L. W.

1904. Problems in the genus Basilarchia. Psyche, xi, 1-6, $3 \mathrm{pl}$.

New COMB, H. H.

1907. Description of a new variety of Limenitis ursula. Psyche, xiv, 90-91, pl.

ScuDnER, S. H.

1889. The Butterflies of the Eastern United States and Canada, with special reference to New England. Cambridge. 


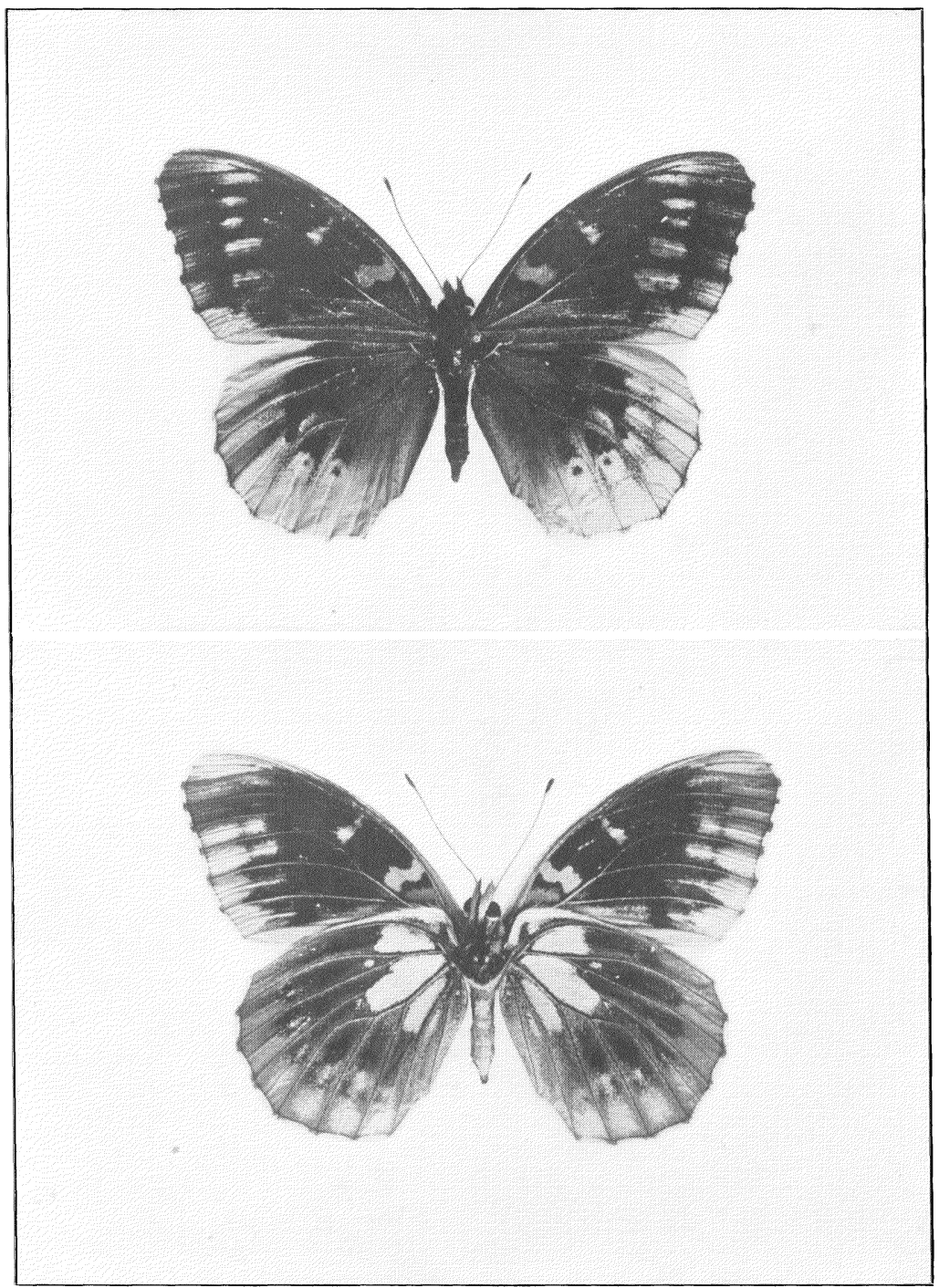

NEWCOMB-ARGYNNIS CYBELE FABR., VAR. BAAL STRECK. 

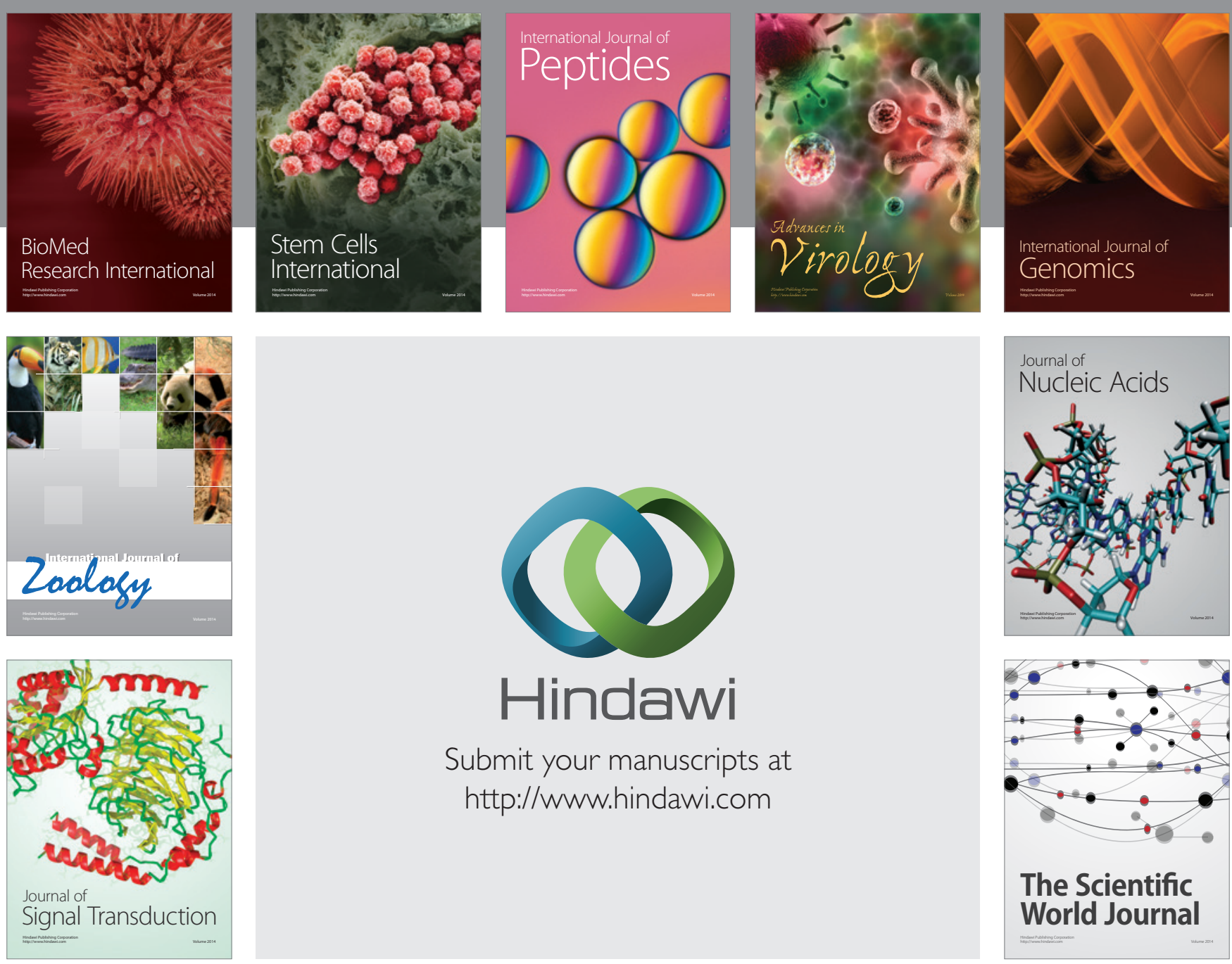

Submit your manuscripts at

http://www.hindawi.com
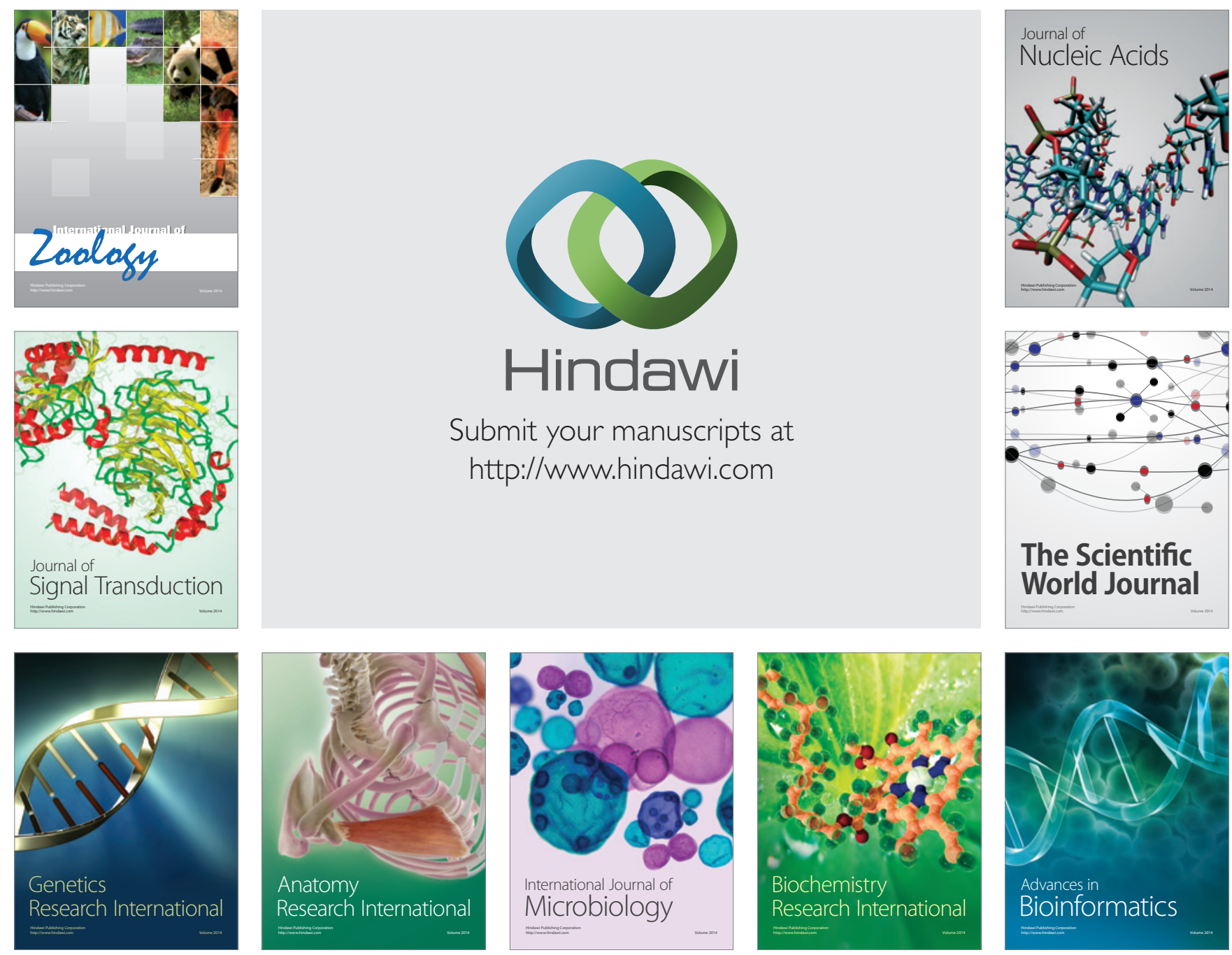

The Scientific World Journal
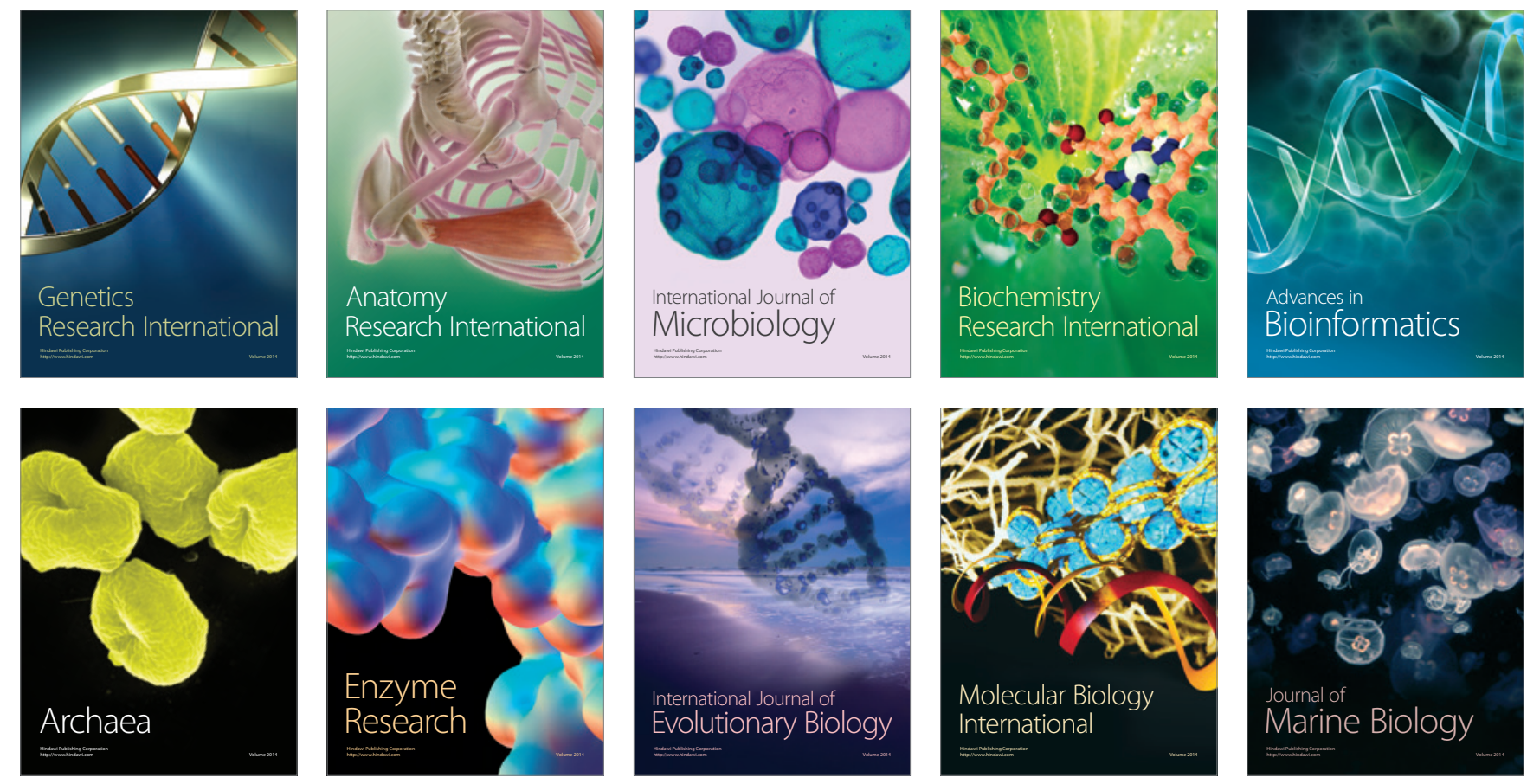